
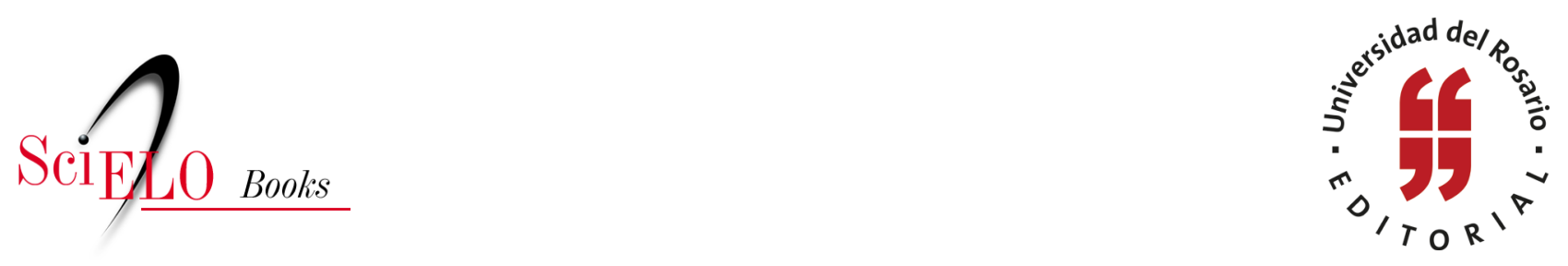

\title{
9. El segundo nombre de mi mamá es Inés
}

\author{
César Augusto Tapias Hernández
}

\section{SciELO Books / SciELO Livros / SciELO Libros}

TAPIAS HERNÁNDEZ, C.A. El segundo nombre de mi mamá es Inés. In: Historias de familia: Etnografía delirante sobre el amor, la violencia y las drogas [online]. Bogotá: Editorial Universidad del Rosario, 2014, pp. 37-40. Textos de ciencias humanas collection. ISBN: 978-958-738-543-4.

https://doi.org/10.7476/9789587385434.0010.

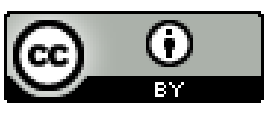

All the contents of this work, except where otherwise noted, is licensed under a Creative Commons Attribution 4.0 International license.

Todo o conteúdo deste trabalho, exceto quando houver ressalva, é publicado sob a licença Creative Commons Atribição 4.0.

Todo el contenido de esta obra, excepto donde se indique lo contrario, está bajo licencia de la licencia $\underline{\text { Creative }}$ Commons Reconocimento 4.0 . 


\title{
9. El segundo nombre de mi mamá es Inés
}

\author{
Dispénseme usted, señora... me sería penoso que usted me \\ encontrase mal educado... no la he saludado antes, aunque me \\ parece, por no decir que tengo la seguridad, de que ya nos hemos \\ encontrado otra vez. \\ Lajos Zilahy, Las cárceles del alma
}

Hay cosas que se le graban a uno en la cabeza, como recuerdos habitados por nostalgias, idas, afectos enredados, días de colores, imágenes como fotos de hasta olores que se quedan detenidas en la mente; pero otras definitivamente las asume uno como marcas bien afinadas hasta constantes: posturas, pensamientos, actitudes, que le otorgan identidad a lo que será uno... De los primeros, tengo yo uno bien bonito: una vez mi mamá me contó que se presentó a la Universidad de Antioquia, quería estudiar enfermería; aunque hoy, creo, debió de pensar mejor en economía, negocios o administración, y eso me lleva al segundo caso. Mamá desde hace mucho tiempo organiza natilleras: forma más popular de ahorro con énfasis en la consolidación de la comunidad, jamás he conocido.

Aunque se evaden de los bancos justificados en el tres por mil y otros tipos de impuestos, desde siempre es claro que plata reunida, prestada al interés y repartida al final con ganancias y divisas... es también, además del desvare en un fin de año, salvación en cualquier momento para el ahorrador que sin muchos trámites recibe un préstamo facilito, de pronto firmando una letra y ya. Y ahorrando así, semanalmente, la gente se atrasa y entonces debe pagar multa... Y ahí está mi mamá cobrando.

"Y mejor que se atrasen bastante, porque por ahíse va haciendo plata", dice mi mamá: Rubiela Inés Fernández Quiroz. Ella es quien propone y organiza las rifas, los paseos y demás actividades de modo que le sumen a la cuota semanal... de la que llevan registro tanto los socios como mi mamá. Registros en libreticas y cuadernos argollados... Un sistema computarizado enredaría la cosa. Mamá de gafas sentada 
al comedor, su cuaderno lleno de cuadros, uno por cada mes, divididos a su vez en cajones: las semanas del mes numeradas del uno al cincuenta... Ahí anota las cuotas pagadas y lleva el registro de los préstamos e intereses. Como recuerdo también tengo que a mi mamá no es que le guste mucho su segundo nombre. A mí por lo menos me parece hermoso. El Inés como tal me trae a la mente a la mamá Inés, a quien le canta "Bola de nieve" un negro gordo cubano, mientras acaricia su piano: “todo' lo’ negro’ tomamo' café ay mamá Inés... todo' lo’ negro’ tomamo’ café...”.

Y mencionando el café en la cancioncilla esa, recuerdo el café de mamá, sobre todo el que prepara de sobremesa para la comida la más de las veces. No he probado otro igual. Pero es que detrás del café hay mucho más: la primera lección de cocina, de sobrevivencia, más bien, que a mi hermano y a mí nos dejó mamá: montar cada día, temprano en las mañanas el agua de panela. AGUA DE PANELA para el chocolate, AGUA DE PANELA, un poco de leche y la cantidad precisa de café, de modo que no perturbe el sueño. Y aun así medio disuelto el café. Termina uno y en el fondo de la taza huellas de nuestro producto nacional. De más pelao me armaba figuritas, unas manchitas regadas ahí no más... aunque me quedaban mucho mejor las que hacía con los restos de chocolate: flores, mariposas... y las flores terminaban comiéndose a las mariposas. Lo del café era como otra técnica y tenía su truco... El chocolate es, sin duda, mucho más manejable.

Bueno, volviendo a los negocios, mi mami se arma constantemente propuestas para procurarse un billete, y ahí va uno delineándola... Si bien eso no le han dejado fortuna económica alguna, nunca se la pilla uno fuera de base: siempre tiene algo por ahí pa’ desvararnos salvándonos de quincenas tan largas... Si no que lo diga mi papá. A mí, por lo menos, desde 2000 pesos para un pasaje al centro, 200.000 y algo más para tiquete aéreo a Cuba, un millón y tanto para una película o el primer capítulo de una novela... Su franquicia es ella misma: no fue a la U, pero las ganas de estudiar no se le agotan: peluquería, panadería, arreglos florales, culinaria y mucho más... Y en eso se encarreta ella, y hace de lo que aprendió y lo vende, o enseña y al hacerlo cobra: decoración de piñatas, elaboración de velas, arreglos navideños... Eso es lo que le da unos pesitos, puro estudio... Lo último si bien no le ha dejado ganancias económicas, tal vez sí muchas espirituales: la Biblia. No es pastora ni nada de eso; solo hace las lecturas en algunas misas y estoy seguro de que, como ella, pocas con la misma convicción y entrega... Mamá es muy creyente, y nunca ha protestado por nuestra poca convicción, aun después de insistirnos mucho en la religión, ¿̇resignada? No sé, eso sí más tranquila porque nos confía a su Señor. 
También la recuerdo mucho cuando en las tardes oía "Pase la tarde con Caracol”. Se dedicaba a mirar sus flores en el patio... La habitaba en aquellos días cierto amor: correteaban sus pelaos por la casa, y ella era feliz. Pero al final, creciditos ya, nos dimos a corretear fue por las esquinas y calles del barrio, y a la cucha de a poquito el sueño le quitábamos... Un día me encontró un superfierro metido entre mi ropa: un trabuco calibre 16. Y ¡lloró mi mamá! La sorprendía el hijo que tenía. ¡Estaba probando cucha!, preferí mejor las palabras y las películas, me estoy haciendo palabrero y cineasta... (Sí, sí estoy matando gente; pero en los cuentos)...

Siempre en la noche mi mamá buscaba el sueño frente a la televisión y me pedía que, por favor, no lo apagara. Su soledad en aquel cuarto no la aguantaba, aunque jamás lo confesó. El poeta panameño Rubén Blades parece cantarle a mi mamá en "Las cuentas del alma”, y yo me imagino cantando esa canción en algún café famoso solo para ella. Ha pasado el tiempo y un poco más grande, me veo un poco altanero con el destino: sus hijos seguimos teniendo una madre joven con ganas de ser todavía... Y nos pelea y nos pelea aún por el desorden... Todas las noches se va a dormir temprano. Al otro día ameniza sus mañanas con la radio encendida en las noticias... Lee también mi mamá, pero ya no tanto como antes, satisfecha seguro de que el vicio ese lo cogí yo... Le interesa de vez en cuando darse otros aires: sentada o recostada en el sofá, despide algunas tardes con un café caliente como pasante a los suspiros que, encontrados por las palabras, las palabras mismas le regalan durante sus lecturas: "las pestes" de Camus, algo de Capote y algunas novelas a las que ha renunciado espantada por los nombres raros: Las cárceles del alma, del húngaro Lajos Zilahy: "Era un día de septiembre; las siete de la tarde. Desde las colinas de Buda, oíanse los lamentos de un tárogato que parecía cantar un adiós al verano”.

Son los recuerdos finalmente lo que nos llenan la existencia. Ahora mismo sé de uno que a mi memoria ofrezco acompañado de un son cubano: "Mamá, yo quiero saber de dónde son los cantantes...”.

Eso es lo que siempre busqué en los discos, de dónde eran los cantantes. ¿Desde cuándo compro yo discos, Inés? ¿ Recordás, por ejemplo, mi inquietud por la música instrumental? Estando muy pequeño me compraste un long play de villancicos. $\mathrm{Al}$ angelito de la carátula lo miré durante todo el viaje de regreso a casa; se parecía mucho a mi hermanito Carlos.

“¿De dónde serán?¡Ay, mamá!” Los cantantes, los embusteros palabreros (los etnógrafos)... ¡Ay, mamá! ¿De dónde serán? 
Sobreviene la pregunta respecto a ¿cuál es el grado de efectividad de este mensaje sociológico?, respondería que... solo quiero hacer/conocer nuestra forma social de interactuar, de ser, de vivir. Y este hacer/conocer remite a un asunto metodológico con implicaciones políticas: cada repertorio de conocimientos fue obtenido conversando, no interrogando ni siguiendo un cuestionario establecido. Se trató de un ejercicio etnográfico que incluyó, además de su escritura o transcripción, la lectura posterior entre quienes la hicieron posible. Un ejercicio de reflexividad que nos permitirá maniobrar con mayor libertad a la hora de seguir siendo parte de este mundo. 